\section{"GIMME SHELTER?" CLOSELY HELD CORPORATIONS SINCE TAX REFORM}

\section{GEORGE A. PLESKO*}

The Tax Reform Act of 1986 (TRA86) changed a large number of incentives facing individuals and corporations. One area where individual and corporate tax incentives interact the most is in the tax treatment of closely held businesses, ' where owners can choose whether to be subject to individual or corporate tax treatment. In this paper, l outline the changes in the incentives facing these firms and describe several trends that have emerged in business organization and activity.

This paper generally limits its discussion to corporations, rather than other types of business forms. However, other types of business forms may achieve most if not all of the same objectives achieved by the use of the corporate form. ${ }^{2}$ At the end of this paper, I address some of the emerging issues in the use of noncorporate entities and recent proposals that may affect both corporate and noncorporate closely held businesses.

\section{TAXATION OF CLOSELY HELD CORPORATIONS}

Regardless of whether an entity is formally incorporated, the Internal Revenue

*Northeastern University, Boston, MA 02115
Code (IRC) requires it to be taxed as a corporation if it "more nearly resembles a corporation than a partnership or trust." The IRC treats corporations as separate entities from their shareholders and is liable to a separate tax under subchapter $C$. Income earned by a corporation will be taxed first at the corporate level and again at the individual level as earnings are distributed.

Subchapter S was enacted in 1958 to allow "small" businesses to operate as corporations without the corporate tax consequences. ${ }^{4}$ These rules were substantially revised in 1982, making $S$ elections even more attractive. The key element to note is that subchapter $S$ corporations possess the same nontax characteristics as any other corporation, but for tax purposes they are treated more closely to partnerships. Therefore, income will generally be subject to only one tax, at the individual level.

To be eligible for federal tax treatment as an $S$ corporation, a corporation must meet all the conditions of IRC $\$ 1361$. These conditions restrict the number and the type of shareholders to 35 individuals (with married couples counting as one ${ }^{5}$ ), with the exception of some estates and 
trusts, and no shareholder may be a nonresident alien as a shareholder. In addition, the corporation may have only one class of stock, and the type of business is restricted. For example, members of affiliated groups, certain financial institutions, subchapter L. insurance companies, possessions corporations, and Domestic International Sales Corporations (DISCS) or former DISCs are ineligible.

\section{ROLE OF ORGANIZATIONAL FORM IN TAX-AVOIDANCE STRATEGIES}

The benefits of operating as a taxable (C) or pass-through (S) corporation depend upon the relative tax rates on corporate and individual income. ${ }^{6}$ Consider a business operation under the tax structure prior to the passage of TRA86 when the maximum tax rate was 50 percent for individuals and 46 percent for corporations. If an $S$ corporation was chosen for a startup venture, the tax benefits would flow directly to shareholders. Losses in the early years of operation would be passed through directly to the shareholders to offset other income in the current year. Without an $\mathrm{S}$ election, all losses would remain in the corporation to be carried forward to offset future corporate income. This immediate use of losses yields a higher present value of tax savings. If the owners of the corporation were in the highest individual tax bracket, the losses could offset a greater amount of tax liability at the individual level than at the corporate level, even absent present value considerations.

If the corporation became profitable, income would flow through to shareholders largely untaxed at the corporate level. However, with individual tax rates higher than the corporate rate, income flowing through to shareholders could face a heavier tax burden than income that is taxed only at the corporate level and is retained. Were the owners to terminate their $\mathrm{S}$ status and become a taxable (C) corporation, only income distributed to shareholders in the form of dividends would be subject to a double tax; retained earnings would be taxed only once, at the corporate level.? Thus, the after-tax amount of income could be greater by electing to be taxed at the corporate level. ${ }^{8}$ As the corporation grew, the value of outstanding stock would also rise as the corporation's assets increased. If a shareholder wanted income, it could be obtained through a sale of stock, which had the additional benefits of basis recovery and a lower tax rate if it qualified as a long-term capital gain. The net effect of these transactions would be to reduce the impact of the double tax on corporate income. $^{9}$

Other strategies exist to remove income from a corporation without being subject to a double tax. Wages, salaries, compensation paid to officers, and employee benefits are all deductible expenses of a corporation. Were a corporation to pay out all of its earnings as employee expenses, only the individual tax would apply, assuming the expenses were included in the gross income of the employees. Deductible expenses not included in an employee/shareholder's income would not be taxed at either level.

Finally, given the deductibility of interest payments, a corporation that finances its growth through the use of shareholdersupplied debt would only be taxed once (at the individual level).

\section{EFFECTS OF TAX REFORM}

TRA86 dramatically changed the incentives for using the taxable corporate form to defer the recognition of taxable income. The centerpiece of the 1986 law was to shift $\$ 120$ billion of tax payments from individuals to corporations over 5 years. While both individuals and corporations saw their tax rates fall, the maxi- 
mum corporate rate was made higher than the maximum individual rate (34 versus 28 percent $^{10}$ ). As a result, the incentive to leave income inside a corporation to avoid paying taxes was greatly reduced, and the incentive to operate as an $S$ corporation increased.

TRA86 also repealed the General Utilities doctrine. Under General Utilities, a C corporation that sold its assets was able to distribute the proceeds to shareholders, as part of a liquidation, without a corporate-level tax. The repeal of General Utilities meant this income would now be subject to the corporate-level tax. As pass-through entities, $S$ corporations are not subject to an entity-level tax.

One exception to the pure pass-through treatment occurs in the case of a $C$ corporation converting to an $S$ corporation. Such a corporation is now subject to a new "built-in gains" tax on the value of capital gains carried over from the $C$ to the $S$ corporation if the gains are recognized within a 10 -year period. While corporations that converted from $C$ to $S$ prior to 1987 are not subject to this tax, they remain subject to an earlier form of the rule that contained a 3-year recognition period.

The imposition of a new corporate Alternative Minimum Tax (AMT) also made the taxable corporate form potentially more expensive. Even firms with relatively low corporate taxable income prior to 1986 might have become subject to the corporate AMT as the AMT targeted firms with large differences between their financial and taxable income, and those with large depreciation deductions. 11

\section{RECENT TRENDS IN BUSINESS ORGANIZATION}

The effects of TRA86 on organizational choices should be viewed in the context of broader trends over the past 30 years.
Since their inception, subchapter $S$ corporations have generally been a small fraction of the corporate sector. From 195990 , the number of $S$ corporation returns grew at an annual rate of 10.2 percent, compared with 2.5 percent for non-S corporate returns. This growth is more striking if it is broken down into two periods: $1959-86$ versus $1986-90$. The annual growth in the number of $S$ returns was 9.5 percent from 1959-86, increasing to 17.5 percent per year from 1986-90.

Most dramatic was the change following the enactment of TRA86, from 1986-87, when the number of $S$ corporations grew by more than 36.5 percent. As shown in Figure 1,5 corporations now account for nearly 45 percent of all active corporate returns. Of the total number of $S$ corporations, the largest shares are in services (31.8 percent of all $S$ corporations) and trade (26.7 percent). The smallest number of $S$ corporations are in mining ( 1.0 percent of the total), agriculture (3.5 percent), and transportation and utilities (4.1 percent).

With the exception of 1980-81, the growth rate of $S$ corporations was faster than any other form of business. Table 1 presents comparisons of annual rates of growth in types of business organizations for the 1980s. With the exception of nonfarm sole proprietorships for 1981-82, S corporations have grown faster than all other forms of business. Among corporations, the number of non-S returns has actually been declining since 1986 .

While the number of $S$ corporation returns has grown rapidly over the past 3 decades, the typical $S$ corporation remains small compared to other corporations. $S$ corporations accounted for less than 2 percent of corporate assets in 1986. Even with the sharp increase in the number of $S$ corporations since $1986, S$ corporations accounted for only slightly more than 4 percent of corporate assets 
FIGURE 1. $S$ and non-S corporate tax returns

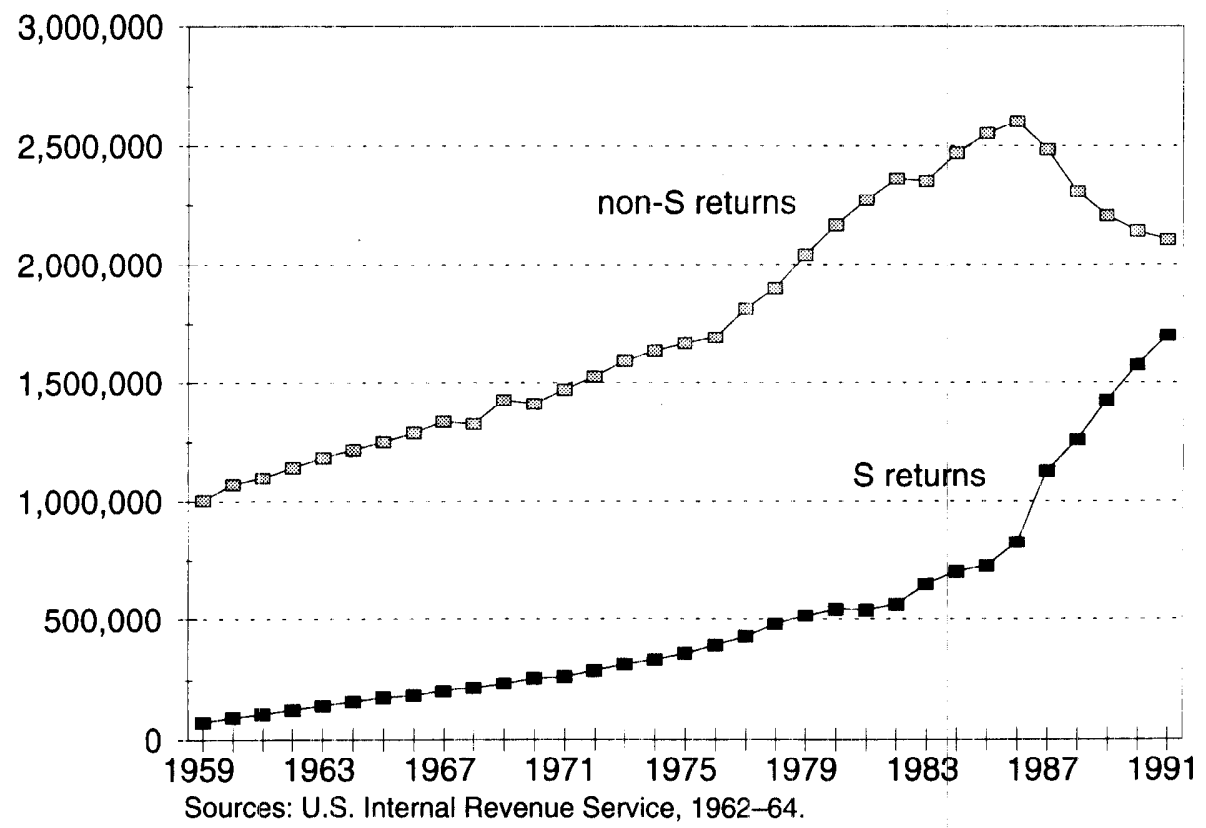

TABLE 1

ANNUAL RATES OF GROWTH IN BUSINESS TYPE, 1980-90

\begin{tabular}{lcccccc}
\hline & \multicolumn{7}{c}{ Time Period } \\
\cline { 2 - 7 } Business Type & $1980-1$ & $1981-2$ & $1982-3$ & $1983-6$ & $1986-7$ & $1987-90$ \\
\hline All businesses & 0.3 & 4.8 & 4.7 & 4.6 & 4.6 & 3.0 \\
Corporations & 3.7 & 4.0 & 2.5 & 4.5 & 5.2 & 1.0 \\
$\quad$ S corporations & -0.7 & 4.1 & 13.9 & 8.1 & 31.1 & 11.1 \\
$\quad$ Non-S corporations & 4.8 & 3.9 & -0.5 & 3.4 & -4.6 & -4.9 \\
Partnerships & 5.7 & 3.6 & 1.8 & 3.3 & -3.3 & -2.0 \\
Nonfarm sole proprietorships & -1.5 & 5.3 & 5.8 & 4.9 & 5.5 & 4.1 \\
\hline
\end{tabular}

Source: Petska and Wilson (1994), p. 33. Time periods reflect periods under similar tax rules.

in 1990. In 1990 the average $S$ corporation had $\$ 472,550$ in assets, compared to a non-S corporation average of approximately $\$ 8.1$ million.

$S$ corporations have been responsible for a growing share of corporate income, and losses. Although $\mathrm{S}$ corporations had only 4 percent of corporate assets in 1991, they were responsible for more than 14 percent of the corporate sector's business receipts. Not surprisingly, the average $S$ corporation's business receipts nearly doubled from 1985-91, from $\$ 574,000$ in 1985 to more than $\$ 1$ million in 1991.

The $S$ corporations' share of net income, deficits, and net income less deficits (NILD) have all risen over time, particularly 
since TRA86. As shown in Figure 2, positive net income of $S$ corporations, which accounted for less than 6 percent of the total prior to 1987 , was more than 12 percent in 1991. Along with the increase in net income, the $S$ corporations' share of deficits also increased, though not as dramatically. The $S$ corporations' share of deficits grew from 11.2 percent in 1986 to 19.6 percent in 1990 .

The overall contribution of the $S$ corporations to the profitability of the corporate sector can best be seen in Figure 3 by examining the trend in NILD. In 1986, S corporations contributed 3.1 percent of the total amount of NILD. In 1987, this amount more than doubled to 7.1 percent of the total, and in 1990, it reached 8.7 percent. These percentages mask the significance of the growth in corporate income attributable to S corporations. In
1986, the 3.1 percent of NILD of S corporations represented $\$ 8.3$ billion. The increase in $\mathrm{S}$ corporation share to 8.7 percent in 1990 represented $\$ 32.25$ billion in NILD - an increase of nearly $\$ 24$ billion, or nearly 290 percent over a 4-year period. That so much additional corporate income is no longer subject to the corporate tax may help to explain why the corporate sector is contributing a smaller amount of revenue to the tax system-an issue of concern to policy makers after TRA86. Plesko (1990) suggested that $S$ conversions after TRA86 could have cost the Treasury as much as $\$ 8.5$ billion in corporate tax receipts. Additional research has suggested that the increase in individual receipts did not offset the decline in corporate receipts. ${ }^{12}$

This sharp increase in $S$ corporation income is also evident on individual tax re-

FIGURE 2. S share of corporate net income

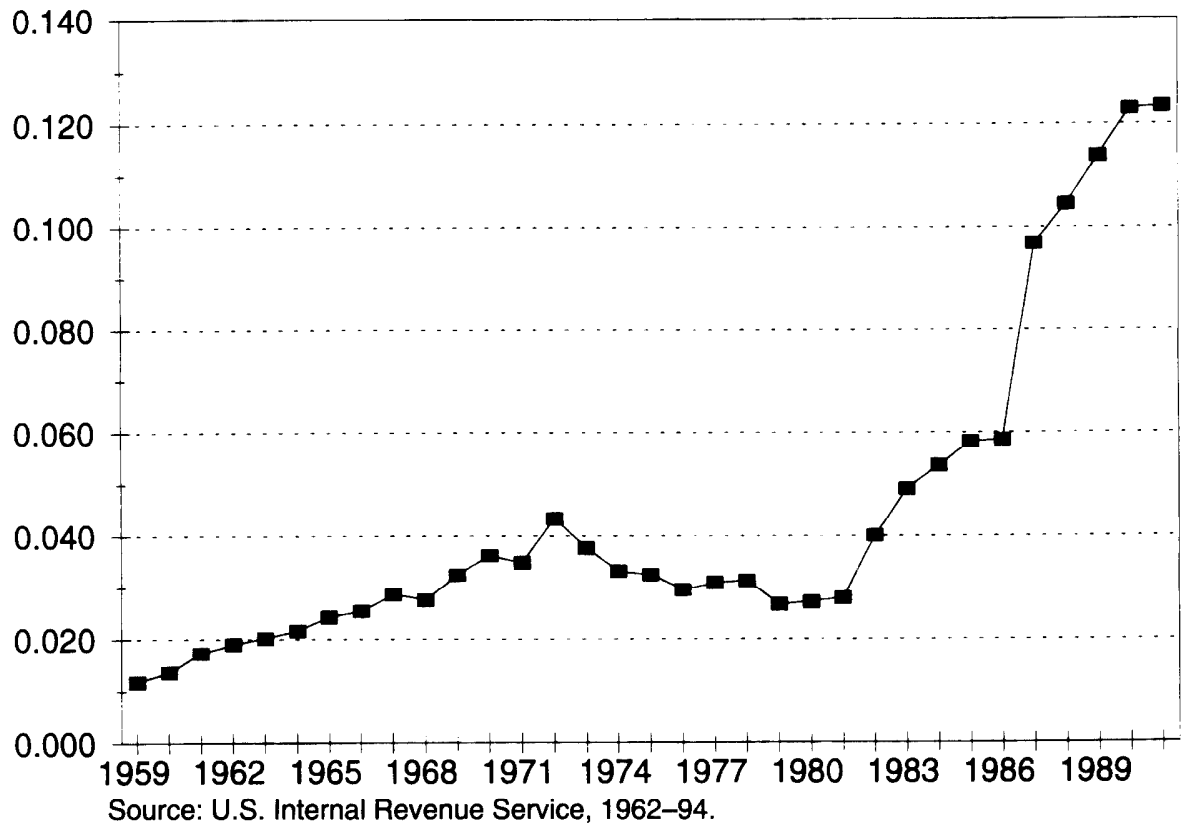


FIGURE 3. S share of net income less deficit

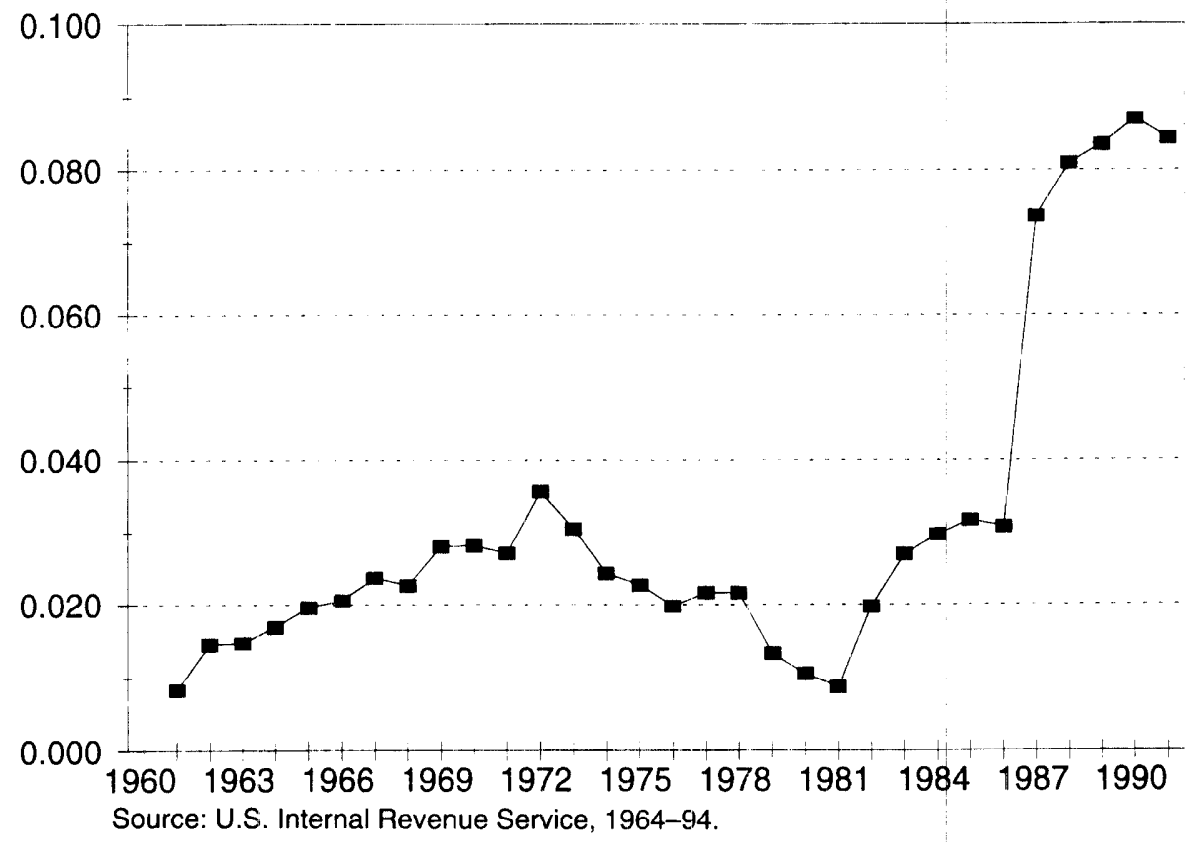

turns. Table 2 shows the amount of business income and loss along with partnership and $\mathrm{S}$ corporation income and loss reported on individual tax returns for $1985-91$.

\section{FINANCIAL CHARACTERISTICS: S VERSUS C CORPORATIONS}

While the change in the number of $S$ and $C$ corporations is dramatic, it is also important to examine the financial behavior of each type of firm. Plesko (1995) finds that the behavior of individual firms to convert (or not convert) from $C$ to $S$ after TRA86 generally followed tax-minimizing strategies. Taxable corporations that did not convert tended to pay less tax than those that converted, and corporations that did not convert paid out a higher percentage of their earnings as interest. Firms that retained higher amounts of their earnings prior to 1986 were also more likely to convert. Among converting firms, the share of firm\$ with losses increased from 17 percent in 1985 to an average of 29 percent in 1986 and beyond.

Dramatic changes appear to have taken place even among firms that did not convert. Of closely held $C$ corporations, dividend payments more than doubled after 1987 , coincident with the individual rate reductions being fully phased in.

\section{RECENT PROPOSALS}

During the past few months two significant changes have been proposed to the rules that govern the tax treatment of closely held corporations.

On March 29, 1995 the IRS released for public comment a proposal to simplify the 
TABLE 2

SOURCES OF BUSINESS INCOME, 1985-91

(DOLLAR AMOUNTS IN MILLIONS)

\begin{tabular}{|c|c|c|c|c|c|}
\hline \multirow[b]{3}{*}{ Year } & \multicolumn{4}{|c|}{ Individual Tax Returns } & \multirow{3}{*}{$\frac{\text { Corporations }}{\text { come Subject to Tax }}$} \\
\hline & \multicolumn{2}{|c|}{ Business Income } & \multicolumn{2}{|c|}{ Partnership \& S } & \\
\hline & Net Income & Loss & Net Income & Loss & \\
\hline $\begin{array}{l}1985 \\
1986 \\
1987 \\
1988 \\
1989 \\
1990 \\
1991\end{array}$ & $\begin{array}{r}98,775.56 \\
110,496.95 \\
123,782.54 \\
145,517.76 \\
152,416.38 \\
161,657.25 \\
162,870.49\end{array}$ & $\begin{array}{l}20,002.99 \\
20,073.19 \\
18,321.91 \\
19,194.51 \\
19,678.70 \\
20,227.06 \\
21,006.47\end{array}$ & $\begin{array}{r}48,477.55 \\
52,403.58 \\
72,370.25 \\
100,918.46 \\
107,373.74 \\
112,029.51 \\
109,117.23\end{array}$ & $\begin{array}{l}51,004.14 \\
58,263.08 \\
48,056.18 \\
43,838.24 \\
44,281.68 \\
45,007.28 \\
45,926.84\end{array}$ & $\begin{array}{l}266,060.61 \\
276,172.50 \\
311,840.62 \\
383,201.98 \\
371,054.51 \\
366,231.16 \\
350,009.71\end{array}$ \\
\hline
\end{tabular}

Source: U.S. Internal Revenue Service, Statistics of Income, Individual Income Tax Returns and Corporation Income Tax Returns, 1988-94.

rules for classifying unincorporated businesses (IRS, 1995). Under current law, a set of four tests are applied to determine whether a firm will be subject to the corporate tax. This proposal was in response to the IRS having to rule on numerous state law changes that created new types of business organizations with largely corporate characteristics, but that were designed to fail at least one of the tests of a corporation..$^{13}$ Under the proposed rules, unincorporated businesses would be able to choose whether or not they wanted to be subject to the federal corporate tax. ${ }^{14}$

Senate Bill 758, the "S Corporation Reform Act of 1995" would make numerous changes in the rules governing $S$ corporations. Among the changes, S.758 would increase the allowed number of shareholders from 35 to 50 , and would allow all family members within six generations to be counted as a single shareholder. The bill would also allow $S$ corporations to issue preferred stock, own wholly owned S corporation subsidiaries, and relax the rules and consequences of an $S$ corporation's earnings of passive income.

Both of these changes would make it easier for many corporations, or corporatelike business, to operate outside of the corporate income tax. Under either proposal, the number of firms subject to the corporate tax will likely decline over time, reserving the corporate tax primarily for publicly traded firms, or those that would face significant costs to change their organization form. To the extent that other types of businesses elected to be subject to the corporate tax, it seems likely that tax avoidance would play an important role in the decision.

\section{Conclusions}

The role of the corporate tax has changed over the 8 years since the passage of TRA86. Trends in the corporate sector, coupled with proposed policy changes at the federal level, suggest a diminished role for the corporate tax among all but the largest companies. While the role of a separate corporate level tax, as well as its overall desirability in a tax system, may be subject to debate, the changes that have occurred since 1986 have taken place with little fanfare. Consideration of changes in the treatment of closely held corporations should not take place in the absence of a discussion of the overall effect these changes may have for the current corporate income tax. To the extent that smaller firms are essentially able to engineer their own form of an integrated corporate tax, attention should be paid to the potential advantages of an integrated system for all forms of business. 


\section{ENDNOTES}

I am grateful to the disc ussant, Eric Toder, for comments

1 The specific definition of closely held in the tax code depends on the attribution rules applicable under the provision. In this paper, I generally refer to a corporation as closely held if the number of shareholders is less than 35 (the current limit for $S$ corporations). This definition is arbitrary, however, as shareholder restrictions are rarely a binding constraint and may be less so in the future.

2 Business organization is one of several activities that can be undertaken to avoid taxes. Cordes and Galper (1985) provide a conceptual framework for understanding and distinguishing various tax-avoidance behaviors.

3 IRC $\$ 7701$ and its regulations, $\$ 301.7701-2$.

4 For $\mathrm{S}$ corporations, small is defined by the number of shareholders, without regard to the amount of assets or other traditional measures of size. For a discussion of tax benefits based on other measures of size, see Holtz-Eakin (1995).

5 A 1994 IRS Revenue Ruling (1994-27) revoking a 1977 ruling makes it easier to structure an operation to effectively include more than 35 shareholders.

6 Plesko (1994) provides cross-sectional estimates on the operating characteristics of $S$ and $C$ corporations prior to TRA86.

7 While two "penalty taxes" (the personal holding company tax and the accumulated earnings tax) target the unreasonable retention of income at the corporate level, strategies exist to eliminate or greatly reduce their threat.

8 This strategy assumes that shareholders are willing to forgo dividend income. If all earning are to be distributed each year, then $S$ would remain the favored form. As explained below, it is possible to remove earnings from a $\mathrm{C}$ corporation without subjecting them to both levels of tax

9 The preferential tax rate on capital gains was eliminated in 1986 when it was set equal to the individual tax rate. A small differential was reintroduced in 1990 when the maximum individual tax rate was increased to 31 percent and the maximum capital gains rate was left at 28 percent. Stock held until death would benefit from the step-up of basis allowed to property acquired from a decedent. See IRC §1014.

10 These tax rates ignore the corporate tax surcharge of 5 percent and the phaseouts of exemptions and deductions in the individual tax. Under changes enacted in 1993, the maximum individual rate was increased to 36 percent and the maximum corporate rate to 35 percent (surcharges may raise these rates to 39.6 and 40 percent, respectively).

11 A $\$ 40,000$ exemption in the AMT is intended to mitigate its effects on smaller businesses.

12 See Plesko (1995). Nelson (1993) provides descriptive information on the recipients of $S$ corporation income.

${ }_{13}$ As of March 27, 1995, 48 states had enacted statutes creating limited liability corporations, and another 23 had enacted legislation to allow for limited-liability partnerships. See Ely and Edwards (1995).

14 See Shefter (1995) for a discussion of the proposed rule.

\section{REFERENCES}

Cordes, Joseph J. and Harvey Galper. "Tax Shelter Activity: Lessons from Twenty Years of Evidence." National Tax Journal 38 No. 3 (September, 1985): 305-24.

Ely, Bruce P. and Allyson L. Edwards. "State Treatment of Limited Liability Companies and Limited Liability Partnerships." Tax Notes 66 No. 14 (March 27, 1995): 2023-6.

Holtz-Eakin, Douglas. "Should Small Businesses Be Tax-Favored?" National Tax Journal 48 No. 3 (September, 1995): 385-94.

Nelson, Susan C. "S Corporations: The Record of Growth After Tax Reform." Journal of S Corporation Taxation 5 (Fall, 1993): 138-61.

Petska, Thomas B. and Robert A. Wilson.

"Trends in Business Structure and Activity, 1980-1990." SOl Bulletin 13 (Spring, 1994): 27-72

Plesko, George A. Declime of Corporate Tax Revenues. Testimony before the Committee on Finance, U.S. Senate, S. Hrg. 101-1065. Washington, D.C.: Government Printing Office, May 3, 1990.

Plesko, George A. "Corporate Taxation and the Financial Characteristics of Firms." Public Finance Quarterly 22 (July, 1994): 311-34.

Plesko, George A. "The Role of Taxes in Organizational Choice: $\mathbf{S}$ Conversions After the Tax Reform Act of 1986." Mimeo, April, 1995.

Shefter, Daniel. "Check the Box Partnership Classification: A Legitimate Exercise in Tax Simplification." Tax Notes 67 (April 10, 1995): 279-84.

U.S. Internal Revenue Service. Statistics of Income: Corporation Income Tax Returns. Publication 16. Washington, D.C.: Government Printing Office, 1962-94.

U.S. Internal Revenue Service. Internal Revenue Bulletin. Notice 95-14. Washington, D.C.: IRS, March 29, 1995. 